\title{
Os olhos tristes da casa, os olhos meigos do boi: Uma leitura de quatro obras do modernismo brasileiro pertencentes ao acervo do MASC
}

House's sad eyes, cow's sweet eyes: A meditation about four artworks from the Brazilian modernis owned by MASC 


\section{Resumo}

O artigo pretende realizar uma reflexão sobre o modernismo brasileiro, ancorada na leitura de quatro gravuras pertencentes ao Museu de Arte de Santa Catarina: duas de Tarsila do Amaral, uma de Mund Júnior e uma de Domingos Fossari. As quatro obras apresentam elementos que nos permitem questionar as relações entre a ideia de progresso e modernização em contraponto com a manutenção de tradições do passado.

Palavras-Chave: modernismo, Tarsila do Amaral, Hugo Mund Junior, Domingos Fossari, MASC

\section{Abstract}

This article aims to offer a reflection about Brazilian modernism through a reading of four etchings owned by the Museu de Arte de Santa Catarina: two of them are by Tarsila do Amaral, one by Mund Junior and the other by Domingos Fossari. The four artworks present elements that propose questions about the relations between progress and modernization versus tradition.

Keywords: modernism, MASC, Tarsila do Amaral, Hugo Mund Junior, Domingos Fossari

ISSN: $1808-3129$ 
Este texto foi motivado por quatro imagens que se irmanam sob o mote "A casa e o boi", pensado como abertura para a compreensão de alguns eixos possíveis de leitura do modernismo brasileiro. A casa e o boi podem ecoar a civilização e a natureza, a escola e a floresta, o humano e o animal, a cultura e o instinto, outros pares também aparentemente duais. Sem pretender abarcar toda a complexidade dessas noções, procurarei apenas pensá-las a partir da proposta de um afrouxamento nas dualidades, ou seja, desejando entender como esses "opostos" que fizeram a narrativa sobre a brasilidade podem não se mostrar como polos estanques. As imagens, pelo contrário, desafiam nossos conceitos, indagam e sugerem sempre novos movimentos, em seu dinamismo.

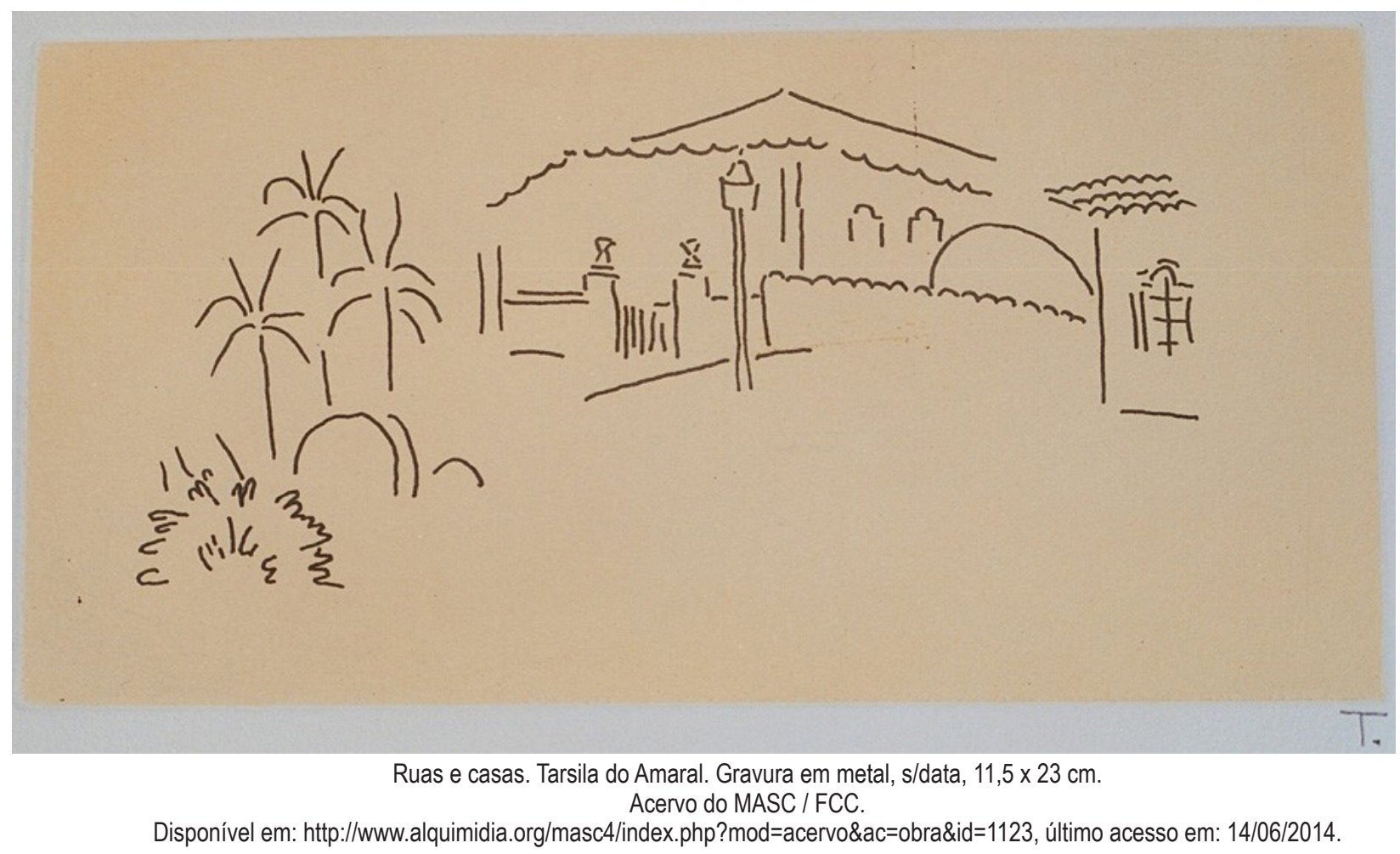

Inicialmente, as imagens pedem que se discutam alguns aspectos conceituais sobre o modernismo brasileiro e a leitura que podemos fazer dele. Algumas das reiterações narrativas que se estabeleceram historicamente têm de ser revistas, a fim de que consigamos mapear uma complexidade de fatores em constelação, que fazem com que a noção de moderno se imiscua dentro do caldo denso da história como a entendemos hoje, a partir de Benjamin. Os sentidos do modernismo serão lidos a contrapelo, a partir do desejo de ir além da noção que nos acompanhou nos manuais escolares, e provocando-a para que dela se desentranhem outras leituras, outras possibilidades.

As imagens também nos fazem pensar sobre a Semana de 22 lida nessa clave: apresentam-nos um modernismo que por vezes passou ao largo do grande evento e de suas consequências. Nessas gravuras e no desenho escolhidos, não vemos o progresso de São Paulo, a industrialização, as altas e baixas do café, elementos presentes na maior parte dos discursos sobre o modernismo brasileiro. Podemos pensar esse mote "Semana de 22" não como fato, porém como um "acontecimento" gerado por 
reiterados discursos críticos que o colocaram em voga. É possível lê-lo então a partir de pressupostos contemporâneos, partindo da definição deleuziana do termo destacado: "O acontecimento não é o que acontece (acidente), ele é no que acontece o puro expresso que nos dá sinal e nos espera. (...) ele é o que deve ser compreendido, o que deve ser querido, o que deve ser representado no que acontece." (DELEUZE, 2007, p.152). Indo além da percepção dos documentos como atestadores de fatos e da construção linear da narrativa histórica cronológica, podemos entender como o evento modernista se construiu a partir da adição de discursos que formam uma série e instauram o acontecimento.

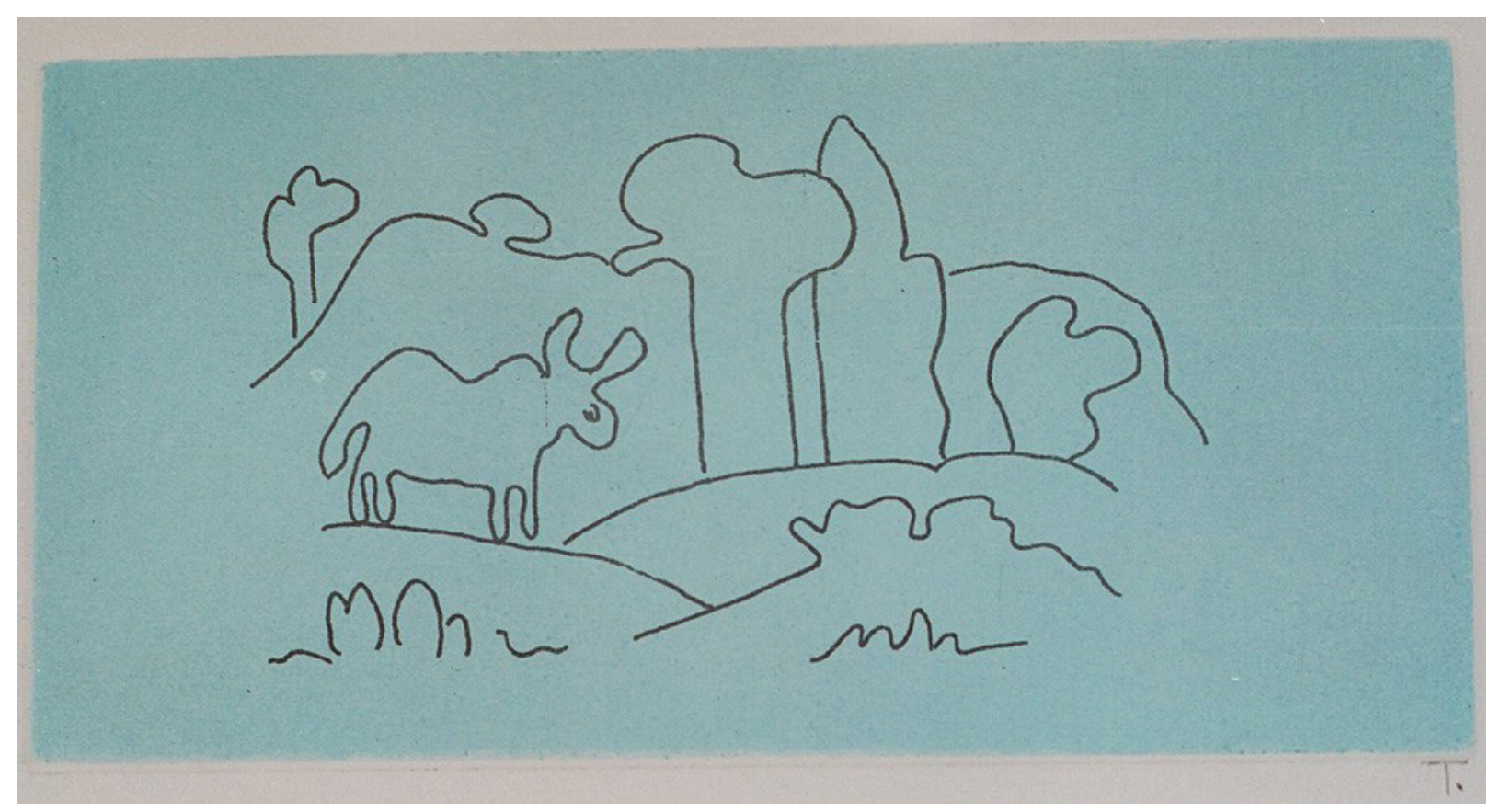

Boi. Tarsila do Amaral. Gravura em metal, s/data, $11,5 \times 23 \mathrm{~cm}$. Acervo do MASC / FCC.

Disponível em: http://www.alquimidia.org/masc4/index.php?mod=acervo\&ac=obra\&id=1121 . último acesso em: 18/05/214.

A Semana é um movimento mental, discursivo, assim como o modernismo é não apenas a Semana de 22, mas um amplo conjunto de operações que vieram antes e depois dela. Há muitos modernismos possíveis. $O$ boi puxando o engenho de farinha, o touro imerso na paisagem, a fachada da casa colonial, o enigma do jardim exuberante de folhagens: tudo isto faz parte de um modernismo estendido, dilatado, disforme, descontínuo, e que afronta os refrões do discurso canônico sobre o modernismo no Brasil.

As imagens também pedem que discutamos o apego cultural brasileiro a uma leitura do seu modernismo à luz das vanguardas europeias, para repensá-lo; já que se aproximam antes ao Retorno à Ordem do que aos movimentos de ruptura do início do século XX. Como pontuam diversos pesquisadores contemporâneos ${ }^{1}$, é possível pensar a irrupção de uma nova estética como movimento complexo que iniciou antes de 22 e sobrepôs esta data, pela lógica da temporalidade desviada, para muito além da cronologia a que a leitura linear a constrangeu. 


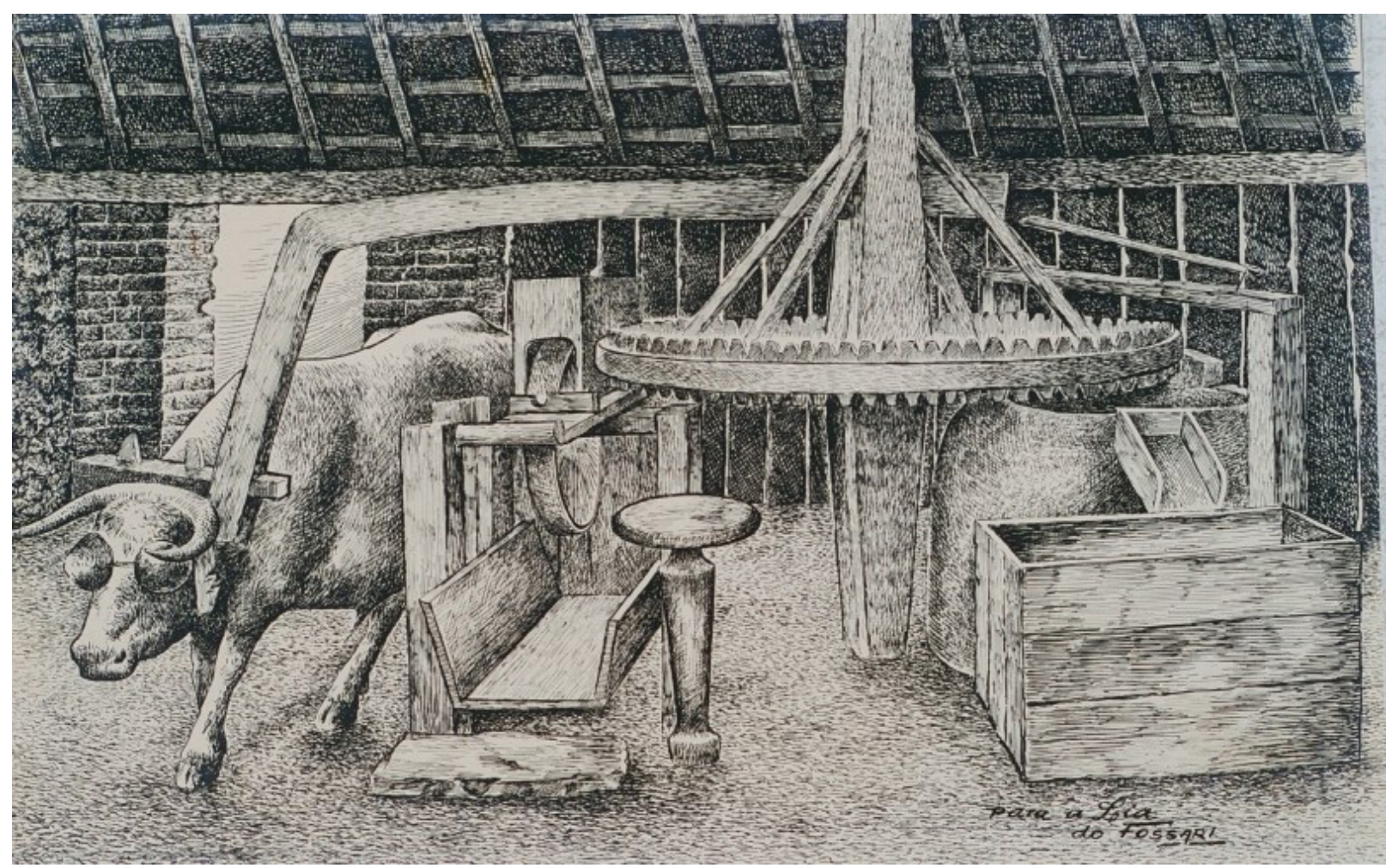

Engenho. Domingos Fossari. Nanquim sobre papel, s/data, 26 x $41 \mathrm{~cm}$. Acervo do MASC / FCC

Disponível em: http://www.alquimidia.org/masc4/index.php?mod=acervo\&ac=obra\&id=894, último acesso em: 14.06.2014.

Dentro do contexto das ações de Oswald de Andrade, Mário de Andrade e outros propositores daquele período, sobressai a noção de antropofagia, que pode ser aproximada das leituras sobre o país que foram feitas por alguns intelectuais dos anos 30, como Gilberto Freyre e Sérgio Buarque de Hollanda. O apelo à ancestralidade, a busca de um passado, das raízes mesmas do Brasil, aconteceu no irromper de alguns ensaios clássicos que procuram analisar a história brasileira. As imagens escolhidas se irmanam a essa busca: são parte de um retorno às origens, são desejo de um conhecimento de si; são espelhos turvos e cheios de sonho e imaginação, mas ainda assim são fruto da necessidade de uma autoconsciência brasileira.

Essas imagens também pedem que reflitamos sobre as configurações do espaço que se podem construir a partir delas, para procurarmos entender como o dentro e o fora operam em colaboração para a formação de uma compreensão de si mesmo que o Brasil formou: assim, a exterioridade dos padrões que as vanguardas europeias construíram, a exterioridade que a cultura opressora do europeu procurou imprimir na construção do novo mundo, são digeridas na intimidade da nossa construção de forma a criar um dinamismo muito atuante e complexo em relação à construção da identidade nacional. Absorvendo no gesto antropofágico, deglutindo e parindo novas formas de ser e estar no mundo, também oferecemos ao mundo uma visão da nossa intimidade, numa dialética que não pode deixar de abarcar esse momento no qual fazemos de nossos elementos mais interiores uma exposição crucial. E assim como os artistas brasileiros absorveram lições do europeu, também a ele ofereceram o fruto do seu criar. 


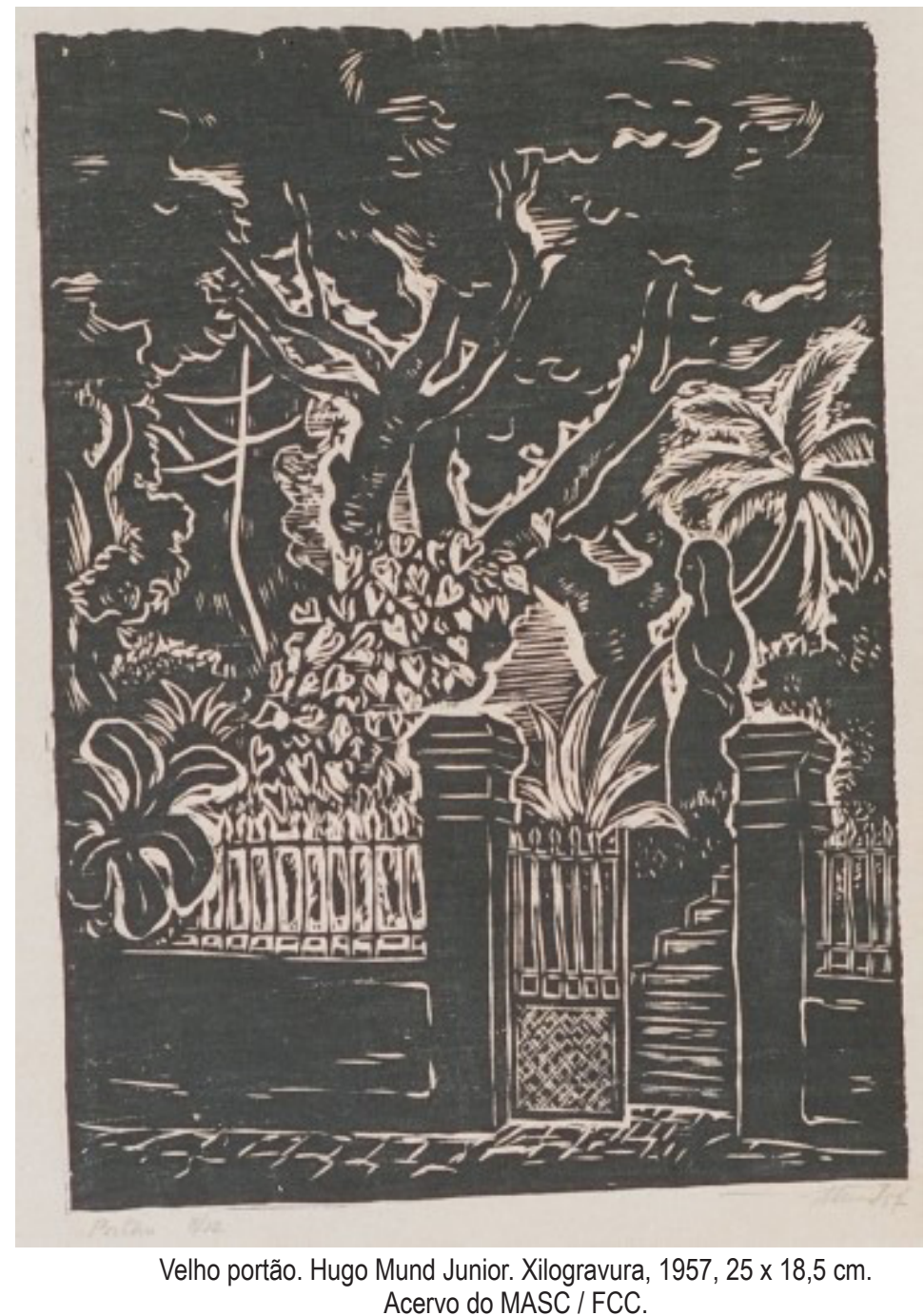

Disponivel em: http://www.alquimidia.org/masc4/index.php?mod=acervo\&ac=obra\&id=92, último acesso em: 16.06.2014.

Inicio esse percurso de leitura a partir de algumas informações sobre as imagens escolhidas. As duas primeiras são de autoria de uma artista que ficou muito conhecida como participante do movimento modernista. Apesar de não estar presente na Semana de 22, pois ainda estudava pintura em cânones acadêmicos na Europa em fevereiro daquele ano, Tarsila encantou-se com as propostas do grupo logo que veio a conhecê-lo mais de perto, ao retornar ao Brasil meses depois. ${ }^{2}$ Através de Anita Malfatti, conheceu Oswald de Andrade, Mário de Andrade e Menotti del Picchia, com quem as duas pintoras formaram um grupo instigado para as renovações estéticas. Ofereceu uma contribuição marcante tanto para a formulação da estética Pau-Brasil quanto da Antropofagia. Tendo vivido com Oswald de Andrade, acompanhou a fase na qual ele formulou o manifesto e o livro de poemas Pau Brasil, tendo um conjunto importante de trabalhos intitulado com a mesma expressão, as pinturas realizadas de 1924 a 1928. A primeira data é também o ano da publicação do Manifesto da Poesia Pau Brasil e a segunda do Manifesto Antropófago 3 . Tarsila também contribuiu decisivamente para a criação da Antropofagia, já que o Abaporu, tela feita para presentear

2 Cf. biografia da artista disponível em www.tarsiladoamaral.com.br, último acesso em: 12.06.2014.

3 ANDRADE, Oswald. Do Pau-Brasil à Antropofagia e às utopias: Manifestos, teses de concursos e ensaios (Obras Completas VI). Rio de janeiro: Civilização Brasileira, 1970. 
seu então marido Oswald, foi o disparador do processo de elaboração dos conceitos antropofágicos:

Em janeiro de 1928, Tarsila queria dar um presente de aniversário especial ao seu marido, Oswald de Andrade. Pintou o 'Abaporu'. Quando Oswald viu, ficou impressionado e disse que era o melhor quadro que Tarsila já havia feito. Chamou o amigo e escritor Raul Bopp, que também achou o quadro fantástico. Eles acharam que parecia uma figura indígena, antropófaga, e Tarsila lembrou-se do dicionário Tupi Guarani de seu pai. Batizou-se o quadro de Abaporu, que significa homem que come carne humana, o antropófago. ${ }^{4}$

As gravuras pertencentes ao acervo do MASC mostram uma Tarsila atenta às paisagens do Brasil profundo. A artista realizou com seus companheiros, em 1924, uma importante viagem que tinha o intento de ciceronear Blaise Cendrars, que estava no Brasil. Estiveram no Rio de Janeiro durante o Carnaval e a Semana Santa passaram em Minas Gerais. De 1925, conhecemos a tela Touro ${ }^{5}$, bem como muitos de seus quadros das fases Pau Brasil e Antropofágica apresentam elementos que podem ser aproximados aos que vemos nas gravuras: a vegetação, o relevo e a arquitetura típicos de fazendas do interior. As imagens escolhidas, portanto, dialogam intensamente com as demais obras da artista.

Tendo participado dos movimentos principais que configuram a narrativa tradicional acerca dos eventos que imprimiram um novo impulso à arte brasileira, Tarsila do Amaral não apresenta aqui nenhum dos traços que podemos considerar como claramente representativos das ideias vinculadas às vanguardas europeias. $O$ traço é solto, porém não há um esforço cubista ou outros traços que poderíamos apresentar como referências diretas às vanguardas europeias. Também não há resquícios nítidos do academismo que constituiu a primeira escola da pintora.

As duas obras de Tarsila não são pinturas, gênero ao qual ela se consagrou e através do qual conferiu uma visualidade ao movimento modernista. São gravuras produzidas a partir de um desenho solto, livre, simples, que não preenche toda a superfície, sugerindo mais do que descrevendo, cuja tônica não é a documentação da paisagem. As gravuras aludem a paisagens impressas na memória, paisagens também sonhadas, construídas pela imaginação e apresentam elementos comuns a muitas localidades do nosso país.

Hugo Mund Jr. é um artista que também teve aproximações com a literatura, por ter contribuído simultaneamente como poeta e como artista visual para a criação de um imaginário que, anos após a irrupção dos acontecimentos modernistas, aprofundou muitos dos temas que aqueles pioneiros lançaram para a cultura nacional. Seu primeiro livro de poemas é de 1968, porém já nos anos 50 ele integrava o grupo Sul de Literatura e Arte, tendo atuado vivamente no cenário cultural do nosso estado. Trabalhou com Oswaldo Goeldi, tendo estudado as questões técnicas da gravura com bastante pormenor. Produziu uma série de trabalhos em xilogravura e desenho a nanquim, alguns deles sendo publicados como ilustrações em diversos livros. ${ }^{6}$

4 Texto da biografia do site oficial da pintora: www.tarsiladoamaral.com.br, último acesso em: 12.06.2014.

5 Imagem disponível em: http://tarsiladoamaral.com.br/obras/neo-pau-brasil-1950/ . último acesso em: 20.06.2014.

6 http://www.antoniomiranda.com.br/iberoamerica/brasil/hugo_mund_junior.html, último acesso em 12.06.2014, http://www.globaleditora.com.br/autores/buscade-autores/?AutorlD=3716, último acesso em 12.06.2014. 
A gravura escolhida é de 1957 e integra uma série ${ }^{7}$ na qual o artista explora, como na maior parte de suas obras que fazem parte do acervo do MASC, a intensidade das sombras e contrastes produzidos em branco e preto. Há largas zonas escuras nas gravuras, que retratam paisagens urbanas ou semi-urbanas de modo a intensificar o caráter onírico e mágico desses espaços que evocam ancestralidades e um sentimento de suspense. As zonas negras deixam espaço aberto para a imaginação, fazem também com que ocorra em nós uma simbiose entre figuras e fundos, já que apenas os contornos são marcados pelo branco, de modo que não sabemos ao certo o que o preto está preenchendo, o que é figura e fundo.

Em Velho Portão, vemos muitos elementos além do arquitetônico que dá título ao trabalho e que aparece no primeiro plano. Temos a vegetação fulgurante da mata Atlântica, tão abundante e vistosa que duvidamos que se trate de um jardim de casa, pois parece antes a abertura para uma floresta densa. Temos a escada que nos aparece levando até os pés da figura feminina que emerge da escuridão, tão hierática e concentrada que duvidamos por vezes que se trate de uma figura humana, já que sua simbiose com a mata densa é tamanha que surge a dúvida sobre se não se trata de um ser fantástico. Como nas gravuras de Tarsila, aparecem as formas da vegetação exuberante de grandes folhas e linhas sinuosas.

É algo muito diverso o que ocorre no desenho de Domingos Fossari, a última das quatro obras escolhidas. Os traços de Fossari a princípio nos sugerem a função documental da obra. $O$ autor de Florianópolis de ontem ${ }^{8}$ foi também pintor de muitas paisagens ilhoas. Gaúcho que adotou a capital catarinense como terra sua do afeto e da devoção, Domingos Fossari utilizou toda sua perícia e técnica no desenho para registrar cenas de uma cidade que parecia em extinção. Muitos dos casarões retratados nos desenhos do livro Florianópolis de ontem estavam prestes a serem demolidos, ou foram reconstruídos por ele em imagem a partir de relatos e fotografias. A obstinação do desenhista foi responsável pela criação de uma obra bastante vasta de documentação, mas supera em muito essa função, já que a cidade que estava continuamente morrendo e ressurgindo em seus traços era também uma cidade imaginada.

Se o onírico em Mund Jr. é ostensivo, sendo suas gravuras possíveis de compreender a partir de conceitos como fantástico e fábula, a documentação de Fossari não deixa de trazer, menos evidentes, os elementos que nos permitem afirmar que sua Florianópolis é menos concreta do que sonhada por ele e por tantos de seus moradores e visitantes - que através da fruição de suas obras podem passear por um passado ideal.

Esta breve introdução às obras deixa entrever as zonas de encontro entre elas e seus diversos modos de serem modernas. Não estão esmagadas em um breve período de tempo, e embora dialoguem intimamente, não foram concebidas na mesma década e não correspondem a anseios de ruptura vanguardista. Cabe questionar: não seriam essas imagens modernistas já detentoras de uma pós-modernidade latente como esta era entendida na Europa apenas no final do século XX? Cabe procurarmos elucidar um pouco os conceitos que rondam as imagens de Tarsila, Mund Jr. e Fossari

7 CHEREM, Rosangela Miranda, MATTES, Aletea Hoffameister. "As cidades oníricas de Hugo Mund Jr.". In.: Revista Da Pesquisa, vol. 4, n.1, disponível em: www.ceart.udesc.br/revista_dapesquisa/volume4/.../ascidadesoniricas.pdf, último acesso em 12.06.2104.

8 FOSSARI, Domingos. Florianópolis de ontem. Florianópolis: Fundação Catarinense de Cultura, 1985. 
a partir das noções que correspondem ao modernismo e suas relações com o contexto do nosso país.

A narrativa tradicional da história do modernismo brasileiro, como ela era ensinada nas escolas até muito pouco tempo atrás (ainda persistem casos), tratava de dispor eventos em ordem imperialmente cronológica, limitando o moderno a um período estrito e ancorando a transformação dos parâmetros artísticos na celebração da Semana de 22, dando a entender que esta teria sido suficiente e necessária para a irrupção do moderno no Brasil. Procurando organizar e celebrar determinadas ações e autores de um cânone compreensível e motivado pela ideia de ruptura com o passado parnasiano, essa narrativa ganhou muitos adeptos. Assim, aprendemos que os modernistas tinham por intuito quebrar com os paradigmas academistas, o que não deixa de conter muito senso, e que fizeram isto pela negação radical dos padrões anteriores, rebelando-se contra os ensinos dos mestres da tradição e impondo sua verdade fundada em uma libertação nunca antes experimentada - e suficiente - para transformar o cenário das artes e das letras nacionais.

Desconstruir esta narrativa inicia por perceber a sua coerência, pois muitas destas afirmações encontram pontos em abundância a seu favor. O que tem sido criticado por diversos estudiosos é a ênfase que é posta na Semana de 22 como elemento que reuniu jovens artistas que vinham com suas propostas bater na tradição, tornando-se o evento por eles organizado suficiente para alterar completamente o cenário nacional, o qual se reduziu assim aos embates paulistanos entre parnasianos e modernistas, como se não houvesse elementos modernistas antes da Semana ocorrendo no país e como se esta fosse a voz única e definitiva das transformações.

Entender o modernismo como "tradição da ruptura" é o que faz Octavio Paz no seu livro Os filhos do barro ${ }^{9}$, que veio após o célebre $O$ arco e a lira ${ }^{10}$ e se dedica a compreender a poesia moderna em sua complexidade. Paz discorre sobre o pêndulo dialético que existe entre os movimentos estéticos que se sucederam, perguntando as causas de o modernismo ter isolado para si a noção de ruptura, que já estava impregnada nos outros grandes momentos da arte - a ruptura tornou-se então, para os modernos, uma tradição, digna de culto. Buscava-se o novo, dava-se ao novo um valor em si, capaz de fornecer sentido às ações. A análise de Paz ajuda-nos a perceber como os movimentos de vanguarda, no início do século $\mathrm{XX}$, nortearam-se por essa desenfreada experimentação: aparentemente, tudo o que nunca havia tido lugar foi ousado, desde a violência futurista, o non-sense dadaísta, o quadro branco de Malevich, a imersão inconsciente e mística dos surrealistas. $E$, com grande destaque para o nosso assunto, a fragmentação da imagem tridimensional operada pelo cubismo, que trouxe à pintura uma contribuição marcante, pois quebrou com os parâmetros da gramática compositiva que imperavam, com acentos diversos e modelagens as mais díspares, sem ataques estruturais, desde o Renascimento. Picasso e Braque de fato influenciaram de modo inegável todas as rupturas que se executaram não só no Brasil mas na América Latina de forma contundente ${ }^{11}$.

Embora os modernistas brasileiros, a exemplo do casal Tarsila e Oswald, tenham

9 PAZ, Octavio. Los hijos del limo. Barcelona: Planeta, 1995.

10 Idem. $O$ arco e a lira. Rio de Janeiro: Nova Fronteira, 1982.

11 Cf. informações disponíveis no CD ROM Academismo e Modernismo na América Latina / Sandra Makowiecky e Rosangela Miranda Cherem, organizadoras. Florianópolis: UDESC, 2008. 
vivido os ares parisienses e conhecido as tumultuadas criações que surgiam no sentido de propor novidades, a influência que as vanguardas europeias efetivamente tiveram sobre o modernismo brasileiro precisam ser especificadas. Seguindo no exemplo de Tarsila e Oswald, sabemos que durante o ano de 1923 eles travaram contato com a intelectualidade europeia, participando das trocas que se processavam no período em termos de pensamentos artísticos e novos rumos para as criações. Eles acompanharam Cendrars em suas descobertas do Brasil profundo. A nova arte europeia buscava na arte africana e no exotismo primitivo aquilo que, para os brasileiros, não era distante. A influência das máscaras na obra de Picasso, ou a energia com a qual o alemão Carl Einstein procurou compreender a arte tridimensional africana ${ }^{12}$, atestam um interesse que era em tudo diverso daquele que os brasileiros poderiam efetivamente conter.

A Europa era assolada pelo velho. A vanguarda, desde o Futurismo, procurava combater essa poeira de séculos que pairava sobre os artistas. ${ }^{13} \mathrm{~A}$ vontade de incendiar bibliotecas, de detonar a tradição clássica que desde a Antiguidade impunha-se na forma de monumentos sempre restaurados e de pensamentos sempre reiterados, vinha com toda a sua energia propor o novo como recurso. O Brasil, contudo, era novo e renovava-se e inovava a cada dia. As cidades viam erigirem-se os prédios, havia o surto da industrialização crescente, os lucros das exportações. Ainda que esse processo tenha sido mais intenso nos grandes centros do que no interior; acontecia pelas cidades (e em cada uma de um jeito), o movimento, o dinamismo, a construção, a aglomeração urbana. A paisagem mudava a cada dia nos anos 20 e nas seguintes décadas. Mesmo a pacata Florianópolis ganhou a sua ponte pênsil, que foi construída de 22 a 26, e vivia o crescimento urbano que fazia desaparecerem os sinais do passado.

Eram então motivações muito diversas a do Europeu e a do brasileiro. Este tinha um país recente e em vias de construção. Era necessário ainda erigir as bases de uma identidade nacional que também resgatasse valores ancestrais. E justo o passado brasileiro era aquilo que a vanguarda europeia buscava como alimento, com a diferença de que o europeu apaixonava-se pelo diverso, pelo exterior, pelo exótico, enquanto o brasileiro apenas expunha nos foras de Paris as suas entranhas mais interiores.

Para entendermos o modernismo brasileiro podemos, portanto, nos embrenhar nessa dinâmica intrincada que se processou entre os valores que os atores da Semana de 22 absorveram de seus contemporâneos do Velho Mundo e a forma como eles lidaram com essa bagagem, no sentido de construir uma imagem de si mesmos, de entender a brasilidade. Assim, pode-se pensar a Antropofagia como construção que leva em consideração um contexto interessante de conceitos e proposições animadoras. Entender o modernismo brasileiro pode, porém, ser muito mais desafiador, já que muito do que ocorreu aqui esteve à margem das boas relações entre paulistas e parisienses, e já se processava muito antes da Semana de 22 com uma arte naif forte e desigual que se espalhava pelas capitais e também se proliferava nos recantos do Brasil profundo. A capital catarinense teve Eduardo Dias, assim como a arte popular

12 EINSTEIN, Carl. Negerplastik [Escultura Negra] Tradução de Fernando Scheibe e Inês de Araújo. Florianópolis: Editora da UFSC, 2011.

13 "Admirar um velho quadro é verter nossa sensibilidade numa urna funerária, em vez de Inaçá-la adiante pelos jatos violentos de criação e ação. Você quer portanto estragar suas melhores forças numa dmiração inútil do passado, do qual você sai forçosamente esgotado, diminuído, espezinhado?" É o que pergunta Marinetti no manifesto O Futurismo. (TELLES, 1983, p.93). 
mesclava influências das três raças, compondo misturas que fariam inveja a muitas ousadias dadaístas e cubistas.

Por outro lado, o modernismo tinha a missão, nos anos 20 e seguintes, de fornecer imagens que pudessem dar conta da diversidade cultural brasileira, de seus traços essenciais, da importância de seus valores de república jovem que havia conseguido se consolidar. As dinâmicas de nossa formação foram investigadas por grandes ensaístas dos anos 20 e 30, como Gilberto Freyre, Sergio Buarque de Hollanda e Paulo Prado. O Brasil estava mais interessado em se olhar no espelho turvo da história do que em olhar para fora, enquanto que o europeu mirava o exótico dos longes para se abastecer.

A ousadia cubista serviu de parâmetro para Tarsila, que viveu em Paris e contaminou-se da atmosfera vanguardista, sendo aluna de Fernand Léger, entre outros. Ainda assim, nunca houve a radicalidade compositiva de um cubismo analítico entre nós, nem tampouco auto-evidente surrealismo, muito menos dadaísmo. As quatro imagens escolhidas são figurativas, ainda que dentro de um figurativismo mais livre e solto em Tarsila e Mund Jr. do que em Fossari.

A influência mais marcante das linguagens europeias sobre o modernismo brasileiro (e isto também para outros grandes pintores como Malfatti, Portinari e outros) foi o Retorno à Ordem, como especificaram críticos como Annateresa Fabris ${ }^{14}$ e Tadeu Chiarelli ${ }^{15}$. O modernismo brasileiro é rigorosamente figurativista, nada há das experiências cabais do dadaísmo de Zurique, apesar de toda a ousadia de um Memórias Sentimentais de João Miramar ${ }^{16}$, o mais radical experimento formal do romance na época. Há uma questão que incendeia os artistas e intelectuais brasileiros desde o Romantismo e que ainda não se esgotou inteiramente. ${ }^{17}$ É o desafio de levar a cabo a construção da identidade nacional, de tecer narrativas sobre o espaço onde vivemos, de elucidar de onde falamos, o que somos e porque nos diferenciamos do resto do mundo.

Em um período posterior à Semana, mas já presente desde antes, também a vontade de denunciar as mazelas sociais levou ao figurativismo. As imagens escolhidas não se enquadram nesta vertente, mas dialogam intensamente com a construção identitária por outro viés, mais onírico, mais doce e cuja marca da brasilidade é menos ostensiva.

Se a influência das vanguardas europeias não é direta, tampouco essas imagens mostram observância a regras acadêmicas. Elas são gestadas em um espaço diverso destes dois polos, que resulta do diálogo entre o nosso e o deles, entre a documentação e a experimentação, que não obedece à lógica opositiva, mas nasce das nuanças que existem entre cada um dos polos.

A gravura Casas e Ruas, de Tarsila, evoca o espaço urbano colonial. Lembramos das ruelas de Parati ou de Ouro Preto, com suas casas com eiras e beiras, suas luminárias antigas, janelas baixas, portõezinhos que mostram a tranquilidade do lugar. Uma

\footnotetext{
14 Annateresa Fabris, "Modernidade e vanguarda: o caso brasileiro". In: Modernidade e modernismo no Brasil. Campinas, Mercado das Letras, 1994. 15 CHIARELLI, Tadeu. "Entre Almeida Jr. e Picasso". In.: FABRIS, Annateresa (org.). Modernidade e modernismo no Brasil. Campinhas: Mercado das Letras, 1994, pp.57-65.

16 ANDRADE, Oswald. Memórias sentimentais de João Miramar. São Paulo: Globo, 1997.

17 É a opinião de Fabris, revelada em entrevista a Maraliz de Castro Vieira Christo (Revista LOCUS, Juiz de Fora), disponível em: locus.ufjf.emnuvens.com.brl locus/article/download/2268/1623, último acesso em: 15.06.2014.
} 
arquitetura que, a exemplo de muitos outros aspectos da vida que se constituiu no Brasil, mesclou os conhecimentos lusitanos com as influências que vinham da Ásia e da África, segundo Gilberto Freyre. Elementos que os portugueses haviam conhecido nessas terras e que muitas vezes não se adaptavam à Europa foram amplamente utilizados aqui:

\begin{abstract}
Produtos de finas, opulentas e velhas civilizações asiáticas e africanas. Desses produtos, o Brasil foi talvez a parte do império lusitano que, graças a suas condições sociais e de clima, mais largamente se aproveitou: o chapéu-de-sol, o palanquim, o leque, a bengala, a colcha de seda, a telha à moda sino-japonesa, o telhado das casas caído para os lados e recurvado nas pontas em cornos de lua, a porcelana da China e a louça da Índia. Plantas, especiarias, animais, quitutes. O coqueiro, a jaqueira, a mangueira, a canela, a fruta-pão, o cuscuz. (FREYRE, 2004, p.339)
\end{abstract}

Por ter se processado no mesmo período das conquistas lusitanas do oriente, - Brasil recebeu muita influência daquelas terras também tropicais. O que muitas vezes chamamos de "casinhas portuguesas" dessas pequenas aglomerações urbanas do período colonial são, assim, já fruto de uma mistura típica da nossa terra. Muitos dos aspectos que vemos no período colonial brasileiro são mesclas únicas de influências, não apenas transportes da cultura do colonizador. A arquitetura pode ser lida metonimicamente como substituidora do povo, que tanto Freyre quanto Hollanda e Prado vão analisar em seu aspecto de miscigenação, de mistura das raças.

Assim como as casas funcionam como metonímias dos sujeitos, também o boi pode ser lido como elemento imprescindível da colonização e, por isso, sintoma das misturas que nos fizeram. Segundo Paulo Prado, o pastoreio

Facilitou a conquista e o povoamento do solo: só depois de próspera a criação puderam ser tentadas as minas. Antes, morreriam de fome os mineiros no deserto. Logo nas primeiras frotas colonizadoras chegou a Pernambuco, Bahia e São Vicente gado vacum importado das ilhas do Cabo Verde. As expedições que procuravam o interior espalhavam os currais pelos sertões pernambucanos, baianos e sergipanos, indo até o sul do Ceará e do Maranhão. Daí vinha aos centros de consumo pelo próprio pé. Cardim já falava de proprietários que tinham quinhentas ou mil cabeças. No extremo sul o gado aparece pela primeira vez em 1556 quando - narra Southey -, o capitão Juan de Salazar trouxe da Andaluzia para o Brasil sete vacas e um touro. Dessa ponta de gado e do importado do vice-rei do Peru deve-se ter espalhado pelo sul do Mato Grosso e pelas reduções jesuíticas o grande rebanho que rapidamente inçou os campos e pantanais dessa região. (PRADO, 2007, 104)

Podemos compreender a partir disso a importância que o animal exerceu em nossa cultura, sua onipresença na paisagem interiorana, nos festejos populares, de norte a sul. $O$ boi é ainda um dos elementos presentes no folclore nacional em uma diversidade de regiões, do bumba-meu-boi do Maranhão ao boi-de-mamão de Santa Catarina, sem contar sua influência na cultura de todo oeste brasileiro. $O$ boi teve importância para a colonização e para a constituição das atividades civilizatórias, seja nas missões jesuíticas ou no trabalho do colono que se estabelecia e montava o pequeno engenho de farinha do desenho de Fossari, tão característico da ilha de Santa Catarina. 
A casa e o boi são, portanto, elementos que, destarte serem tão comuns a várias culturas (estão presentes nas mais diversas regiões do planeta) têm aqui uma forma peculiar de apresentar suas particularidades, que aludem ao Brasil do interior, da vida rural e dos tempos coloniais. Excedem esses temas, trazendo aspectos oníricos, mostrando a força selvagem em combate com a ideia de organização social, trazem à tona os resíduos dos grandes conflitos que o Brasil viveu em seu processo de colonização.

Em um primeiro momento, a casa parece aludir à civilização, à presença do europeu que adentrou as nossas terras, ao inanimado, sólido, perene; enquanto o boi poderia nos levar a pensar na natureza, nos instintos animais, na liberdade do campo, na solidão da paisagem. Ambos sendo erigidos sobre o fundo da mata virgem como sinais de colonização, de enraizamento de um povo novo no lugar, mimetizam-se com o relevo e a vegetação, integrando-se a esta. Assim, a zona esquerda da primeira gravura de Tarsila mostra a natureza agressiva que verticaliza-se e toma proporções tão importantes no desenho quanto a casa. A gravura de Mund Jr. mostra a mesma presença imperante da vegetação que, de modo interessante, está atrás do portão, além da rua, dentro do espaço que se configura como propriedade particular. É uma mata densa, nevrálgica, sensual e potente, com suas linhas sinuosas.

Paulo Prado afirmou, sobre os colonizadores portugueses, que "Da beleza das paisagens não cuidavam. Não era, nem do tempo nem da raça, o amor à natureza." (PRADO, 2007, 62). Gilberto Freyre também reforça a postura dos colonizadores que, não tendo cuidados para garantir a saúde da terra, antes do final do século XVI já haviam feito improdutivas as grandes extensões de terras litorâneas. A mentalidade era a de explorar, inicialmente limpando-se o terreno com o fogo, destruindo a mata virgem para fundar plantações que não tinham uma vida muito longa e que não alimentavam suficientemente os próprios colonos. Freyre nos põe a par da escassa alimentação dos brasileiros dos primeiros tempos, ao mesmo tempo em que aborda o luxo dos senhores de engenho que aproveitavam as riquezas vindas do oriente, que primeiro aportavam aqui antes de seguir para a metrópole. Contradições advindas do modo como o solo brasileiro foi povoado. As dualidades são também muito exploradas por Sérgio Buarque de Hollanda que, em Raízes do Brasil, seleciona eixos opositivos para abordar sua temática, seguindo a metodologia em voga na época. Ainda que esses ensaios hoje tenham tornado-se ultrapassados em muitos aspectos, principalmente nos quesitos sociológicos; eles conservam o interesse de apresentarem dados historiográficos pertinentes e que podem iluminar a nossa leitura sobre o modernismo, pensando que foram gerados no calor do interesse por vasculhar nossas origens, tentando compreender a brasilidade.

Esses trabalhos teóricos não deixam de ser também a interface dos movimentos artísticos do período modernista, seja o Pau Brasil, o Antropófago, o Terra Roxa e outros. É uma operação símile a que esses pesquisadores, dentro do âmbito da história e da sociologia, levam a cabo. Há uma vontade de conhecer e apoderar-se da brasilidade, de formular as teses que desembocarão nas posturas de valorização do tipicamente brasileiro. Sérgio Buarque de Hollanda, como Oswald e Tarsila, teve uma estada fértil na Europa, mais especificamente na Alemanha, onde conheceu os preceitos de Max Weber que o auxiliariam na redação de Raízes do Brasil. Embora ele 
tenha abandonado muitos desses pressupostos e se voltado posteriormente para a historiografia (é a historiografia o dado mais atual e interessante do livro, segundo Evaldo Cabral de Mello, autor de um interessante posfácio) ${ }^{18}$, a contribuição da problemática do "homem cordial" encontra eco nas leituras contemporâneas sobre o brasileiro.

Interessa dos relatos presentes nessas obras o modo como abordam o esforço do homem no povoamento da natureza selvática, o modo como o europeu aqui assumiu ares muito diversos daqueles que ele tinha tanto na Europa quanto nas outras colônias. A fusão com o índio e o africano, a adequação ao solo, ao clima, à natureza da terra marcou a irrupção de uma maneira de se relacionar com o espaço que deu ensejo a essas visões da vegetação que encontramos nas gravuras tanto de Tarsila quanto de Hugo Mund Jr.

Todas essas dificuldades de povoação e todas essas fusões culturais com os valores da população indígena e africana foram terreno fértil para o surgimento de uma autoconsciência nacional que forçosamente tem de passar pelo onírico, com toda a riqueza das lendas e do animismo. A obra Macunaíma, de Mário de Andrade, talvez seja uma realização aproximável desse movimento que flagro nas imagens que mostram um Brasil tomando posse de seu mistério, encarando-o (embora o herói sem nenhum caráter traga um dose de ironia não encontrável nessas obras) tornando evidente o modo de pensar do brasileiro em sua relação com a natureza selvagem. Quando o herói do romance de Mário de Andrade passa a conhecer o automóvel, formula sobre ele uma lenda, a que explica a sua origem através da evocação de uma onça que passou por uma série de transformações: é também a antropofagia, o pensamento selvagem tomando posse da realidade a ele exterior e reinterpretando-a conforme o seu saber ancestral. Assim, nada há na natureza apresentada por Tarsila e Mund Jr. daquela terra aproveitável que se quis explorar ardentemente através da cobiça. Há uma natureza cheia de mistério e profundidade, perigosa ao mesmo tempo em que atraente, guardando seu segredo apesar e além da casa.

Sem apelar para o folclórico e menos ainda para o regionalista, as imagens escolhidas fornecem visões que o modernismo teceu sobre a sua terra. De modo sofisticado, com muito espaço livre para a sugestão, e de modo suave, sem ter que incorrer na evidência ou na certeza, essas gravuras oferecem uma complexidade de alusões que nos fazem refletir sobre a integração entre homem e natureza nessa busca das origens, das imagens que remetem ao Brasil ancestral.

Assim, a civilidade representada pelo portão com seu gradil de ferro bem trabalhado, símbolo da propriedade privada, da demarcação e da separação, acaba sendo um portal para uma realidade misteriosa, para uma viagem que leva o olhar ao encontro dessas sombras saborosas e frutíferas, onde a árvore é mulher e a mulher, árvore; onde a palmeira faz uma curva mais sinuosa do que o torso da mulher, onde arbustos semelhantes aos da rua de Tarsila lembram também o perigo e a agressividade da selva ao mesmo tempo em que largas folhas encobrem o que lhes está por detrás. O animismo e a cumplicidade entre homem e cosmos estão presentes, dão as

18 "A geração dos anos 30 (a de Sérgio Buarque, Gilberto Freyre ou Caio Prado Júnior) não escapou inicialmente à tentação de dialogar com a geração do primeiro terço do século no próprio terreno em que esta se colocara, vale dizer, no terreno de uma "sociologia da formação brasileira" (...). Mas se as obras de Sérgio Buarque, Gilberto Freyre ou Caio Prado sobreviveram, isto se deveu a que levaram a marca registrada dos grandes historiadores". (HOLLANDA, 1995, p.191). 
mãos nesse ambiente fusional.

A mesma integração com seu mistério e até perigos é a que vemos na segunda gravura de Tarsila, Boi. Um relevo alto e místico serve de fundo a essa figura solitária do boi no campo. O boi parece tranquilo, rodeado das coisas que lhe são próprias: as árvores, as colinas, o pasto alto e abundante. Há algo, porém, nesse boi, que evoca uma ancestralidade. Seus chifres ameaçam o espectador, lembram que ele é fera, que há um instinto que o preside, indevassável, e com o qual habitamos também cotidianamente. Boi e cosmos se completam no perigo desses chifres, na forma sugestiva das árvores. Os vazios deixados por Tarsila fazem com que o mistério ecoe no ambiente. Há algo por acontecer? A ideia de transcendência vem com a figura do boi, na verdade um touro, e seus chifres ondeantes que, mesmo com a suavidade do traço quase infantil, com a meiguice dessa presença simpática, deixam entrever a figuração mística que fez do touro o Minotauro. De fato, a relação entre homem e touro na arte é antiquíssima. Nas pinturas cretenses encontramos jovens e touros em sintonia espetacular. O castelo de Knossos, com seu aspecto labiríntico, enigmático, apresentanos essa importância do touro como elemento que se fez tradição posteriormente na Grécia Antiga. São inúmeras as abordagens, na história das artes e da literatura, desse animal que evoca a complexidade de ser a um tempo fera e amigo, cujos olhos doces casam com a sua imponência, sendo temível e prazenteiro, acolhedor e ameaçador ao mesmo tempo.

No desenho de Fossari, é outro o boi: escravizado, coisificado, não está em seu habitat natural. É força produtiva, move o engenho, não vê. Esconde-se atrás da engenhoca humana, é um boi civilizado - porém, nem por isso, escapa ao teor da imaginação. $O$ ambiente acolhedor do antigo engenho, com seu teto baixo bem construído, suas madeiras protetoras, sua organização, sua limpeza exemplar (não parece estar produzindo) é o lugar não apenas do trabalho de todo o dia (não vemos o trabalho em si) mas é a imagem que procura salvaguardar uma cultura, registrar uma série de valores que poderiam se perder caso a imagem não existisse. As crianças se criariam em um novo mundo, urbanizado e tecnológico, e não saberiam como funcionava e de que se tratava esse mundo da Florianópolis pacata, rural, dos engenhos de farinha, dos alambiques, da amizade hospitaleira, das trocas humanas. O ambiente no qual o boi reside é simbólico, o ultrapassa em sua materialidade que significa um mundo original, ancestral, tão ambicionado por Fossari (como passado a ser salvaguardado) quanto o passado colonial a ser compreendido pelos ensaístas dos anos 20 e 30. A imagem de Fossari auxilia o seu espectador a entender as origens, as raízes da cultura florianopolitana, alude ao seu lado remoto e precioso, é o retrato de uma época inaugural que se perdeu. Nessa tentativa de conservação, o artista imprimiu, conscientemente ou não, um viés imaginário: sonhou sua Florianópolis original, construiu uma narrativa, imprimiu a sugestão em seus traços. Fossari lutava contra a morte das casas, procurava reter suas imagens como a trabalhar para a conservação da ancestralidade da cidade que ele desejava ardentemente que sobrevivesse ao progresso civilizatório. Assim, em seus desenhos também há uma dialética, um jogo e oposições cuja complexidade envolve a busca do passado mítico ao mesmo tempo em que se erige dentro de um contexto de modernização.

Em todos os casos, há um processo de autoconscientização: as imagens ofere- 
cem valores que surgem de um profundo mirar-se, buscar-se, confrontar-se com o passado, com os abismos da origem, com a ancestralidade que mora na natureza, na vegetação pulsante, na casa colonial, no velho portão, no boi e no antigo engenho. São imagens de uma intimidade brasileira, no sentido em que trazem cenários que remontam a esses passados impregnados de sonho, resultados da mistura antropofágica entre as pulsões cosmogônicas e os ambientes civilizatórios. Elas revelam para o exterior o que é íntimo e pulsante.

Escreveu Benjamin que "Articular historicamente o passado não significa conhecê-lo "como ele de fato foi". Significa apropriar-se de uma reminiscência, tal como ela relampeja no momento de um perigo." (BENJAMIN, 1994, p.224) As imagens auxiliam-nos nesta tarefa, pois são elas mesmas o perigo, trazem evocações que não param de colocar-nos diante dessa imagem de si mesmo que o Brasil construiu e que nós continuamente vamos construindo.

Quando Sérgio Buarque de Hollanda olhou para o Brasil e pretendeu dar sua interpretação sobre ele, deparou-se com uma série de inadequações, de lapsos, de problemas (muitos ainda persistem) porém fez isso de acordo com um método que procurava extrair da dialética opositiva os seus resultados. Situados tantas décadas depois, podemos reler esse intuito de uma forma diversa, pensando não nos defeitos de uma falta de ordem e de disciplina, mas nas qualidades que as fusões trouxeram para a nossa cultura, para as possibilidades sofisticadas de pensamento sobre si que o modernismo também construiu. Com os avanços das teorias que procuram analisar o nosso modo de conhecer, deparamo-nos com a obsolescência de conceitos de verdade absoluta e também com a dissolução das oposições binárias cuja estrutura traz consigo uma série de estruturas de poder acompanhando esse modo de pensar. Munidos de um entendimento que procura antes compreender os dispositivos de construção do imaginário, podemos olhar para as gravuras e o desenho de uma forma mais aberta, vendo o modo como evocam as ancestralidades coloniais e o pendor onírico com a riqueza da sofisticação, da complexidade, de uma contundência que se faz pela sugestão e não pela afirmação impositiva. Assim, não deixamos de inscrever nessa leitura jogos que fazem com que as janelas das casas coloniais sejam olhos tão meigos quanto os do boi, assim como o mistério dos arbustos pode inscrever-se como um perigo tão grande quanto os chifres do boi e a silhueta feminina que espera no topo da escada. Homens, casas e bois podem trocar de lugar a todo o momento, íntimo e público fazem-se contíguos, sonho e documento mesclam-se, trazem consigo a virtude de se reescreverem diante de nosso olhar conforme observamo-os.

\section{Referências}

AGAMBEN, Giorgio. O que é o contemporâneo? e outros ensaios. Tradução de Vinícius Nicastro Honesko. Chapecó: Argos Editora, 2009.

AMARAL, Aracy. "A imagem da cidade moderna: o cenário e seu avesso." . In.: FABRIS, Annateresa (org.). Modernidade e modernismo no Brasil. Campinhas: Mercado das Letras, 1994, pp. 89-95. 
ANDRADE, Carlos Drummond de. Reunião: 10 livros de poesia. Rio de Janeiro: José Olympio, 1969.

ANDRADE, Mário de. Macunaíma. Rio de Janeiro: Agir, 2008.

Paulicéia desvairada e Losango cáqui. In.: Poesias completas. São Paulo: Círculo do Livro, 1976.

ANDRADE, Oswald. Do Pau-Brasil à Antropofagia e às utopias: Manifestos, teses de concursos e ensaios (Obras Completas VI). Rio de janeiro: Civilização Brasileira, 1970.

O santeiro do mangue e outros poemas. São Paulo: Globo: Secretaria de Estado da Cultura, 1991.

Memórias sentimentais de João Miramar. São Paulo: Globo, 1997.

BENJAMIN, Walter. Magia e técnica, arte e política: ensaios sobre literatura e história da cultura. (Obras escolhidas volume I). [Tradução de Sérgio Paulo Rouanet]. São Paulo: Brasiliense, 1994.

CHIARELLI, Tadeu. "Entre Almeida Jr. e Picasso. In.: FABRIS, Annateresa (org.). Modernidade e modernismo no Brasil. Campinhas: Mercado das Letras, 1994, pp.57-65.

CHEREM, Rosangela Miranda, MATTES, Aletea Hoffameister. "As cidades oníricas de Hugo Mund Jr.". In.: Revista Da Pesquisa, vol. 4, n.1, disponível em: http://www.ceart. udesc.br/revista_dapesquisa/volume4/numero1/plasticas/ascidadesoniricas.pdf, último acesso em 12.06. 2014.

CHEREM, Rosangela Miranda; MAKOWIECKY, Sandra. Academismo e Modernismo na América Latina / Sandra Makowiecky e Rosangela Miranda Cherem, organizadoras. CD ROM. Florianópolis: UDESC, 2008.

DELEUZE, Gilles. Lógica do sentido. [Tradução de Luiz Roberto Salinas Fortes.] São Paulo: Perspectiva, 2007.

EINSTEIN, Carl. Negerplastik [Escultura Negra]. Tradução de Fernando Scheibe e Inês de Araújo. Florianópolis: Editora da UFSC, 2011.

FABRIS, Annateresa (org.). Modernidade e modernismo no Brasil. Campinhas: Mercado das Letras, 1994.

FOSSARI, Domingos. Florianópolis de ontem. Florianópolis: Fundação Catarinense de Cultura, 1985.

FREYRE, Gilberto. Casa Grande \& Senzala: formação da família brasileira sob o regime da economia patriarcal. São Paulo: Global, 2004. 
HOLLANDA, Sergio Buarque de. Raízes do Brasil. São Paulo: Companhia das Letras, 1995.

PAZ, Octavio. Los hijos del limo. Barcelona: Planeta, 1995.

O arco e a lira. Rio de Janeiro: Nova Fronteira, 1982.

POMPEIA, Raul. O Ateneu: Crônica de Saudades. São Paulo: Ática, 1998.

PRADO, Paulo. Retrato do Brasil: ensaio sobre a tristeza brasileira. São Paulo: Companhia das Letras, 2007.

ROSA, Guimarães. Grande sertão: veredas. Rio de Janeiro: Nova Fronteira, 2006.

TELLES, Gilberto Mendonça. Vanguarda europeia e modernismo brasileiro. Petrópolis: Vozes, 1983. 
Os olhos tristes da casa, os olhos meigos do boi: Uma leitura de quatro obras do modernismo brasileiro pertencentes ao acervo do MASC 